\title{
ЮРИДИЧНА ТЕХНІКА ЗАКОНУ УКРАЇНИ «ПРО ОПЕРАТИВНО-РОЗШУКОВУ ДІЯЛЬНІСТЬ» 1992 Р.
}

Аброськін В. В.

У статті розглянуто поняття юридичної техніки в Зу «Про оперативно-розшукову діяльність» 1992 р. шляхом розгляду комплексу вимог до змісту даного акта. Це соціальна значущість, конституційність, кількісні показники, системність, логічність, мовні правила та формальні вимоги. За допомогою кількісних показників доведено факт поступового збільшення обсягу текстового матеріалу. До числа недоліків акта відноситься необхідність більш чіткого викладення та збільшення обсягу матеріалу стосовно конституційних прав та свобод людей та громадян.

Ключові слова: закон, оперативно-розшукова діяльність, юридична техніка, конституційність; оперативна інформація; кількісні показники.

В статье рассмотрено понятие юридической техники в Зу «Об оперативно-розыскной деятельности» 1992 г. путем рассмотрения комплекса требований к содержанию данного акта. Это социальная значимость, конституционность, количественные показатели, системность, логичность, языковые правила и формальные требования. С помощью количественных показателей доказан факт постепенного увеличения объема текстового материала. К числу недостатков акта относится необходимость более четкого изложения и увеличения объема материала относительно конституционных прав и свобод людей и граждан.

Ключевые слова: закон, оперативно-розыскная деятельность, юридическая техника, конституционность, оперативная информация, количественные показатели.

There are several reasons for the relevance of the research topic. First, the need to counteract crime, which has become threatening in Ukraine. In the conditions of crisis, which covered all spheres of social and political life of the country, its economy, finances, agriculture, there is a sharp increase in the number of crimes, while increasing the level of organization, arms and professionalism of criminal groups. Secondly, the Law on Armed Forces is an effective tool for law enforcement and special bodies to combat crime. This piece of legislation plays an important role in the enforcement, activities of operatives, investigators, prosecutors, courts and lawyers. On the level of legal technology of this law depends on the effectiveness of conducting investigative activities, protection of life and health of law enforcement officers, ensuring the constitutional rights and freedoms of citizens Thirdly, today there is an intensive development of such a field of law as a legal technique, on the basis of which there was a system of methods, tools and techniques that allow to increase the level of preparation and effectiveness of regulatory acts. The achievements of this science, its methods and rules of expedient use as a means of researching the content of the Law of Ukraine "On ARD".

The article deals with the concept of legal technique in the Law of Ukraine "On Operational Investigation Activities" in 1992 , by considering a set of requirements for the content of this act. With the help of quantitative indicators the fact of gradual increase of the volume of text material is proved. The disadvantages of the act include the need for a clearer presentation and an increase in the volume of material regarding the constitutional rights and freedoms of people and citizens.
Based on the results of the study we can draw the following conclusions:

1. The content of the law corresponds to the requirement of social importance, which is to counteract crime, the title of the document corresponds to the content of the act, and the distribution of articles provides the requirement of logic of the attachment of material.

2. It is shown that by means of quantitative indicators the authors of the document paid the greatest attention to the guarantees of legality in conducting the ARD, as well as the fact of a gradual increase in the volume of textual material, which increased almost 3 times between 1992 and 2020.

3. The drawback of the legislative act is the need to clarify and increase the volume of material devoted to ensuring the constitutional rights and freedoms of people and citizens.

Key words: law, operative-search activity, legal technique, constitutionality, operational information, quantitative indicators.

Постановка проблеми. Актуальність теми дослідження пов'язана з декількома причинами. По-перше, це необхідність протидії злочинності, яка набула в Україні загрозливого характеру. В умовах кризи, що охопила всі сфери суспільно-політичного життя країни, їі економіку, фінанси, сільське господарство, спостерігається різке збільшення кількості злочинів з одночасним підвищенням рівня організованості, озброєння та професіоналізму злочинних угруповань. По-друге, ЗУ «Про ОРД» являє собою дієвий інструментарій, за допомогою якого правоохоронні та спеціальні органи проводять боротьбу зі злочинністю. Даний законодавчий акт грає важливу роль у правозастосуванні, діяльності оперативних працівників, слідчих, прокурорів, судів та адвокатів. Від рівня юридичної техніки цього закону залежить ефективність проведення оперативно-розшукової діяльності, захист життя та здоров'я працівників правоохоронних органів, забезпечення конституційних прав і свобод громадян По-третє, сьогодні спостерігається інтенсивний розвиток такої галузі юриспруденції, як юридична техніка, на основі якої з'явилась система методів, засобів та методик, що дозволяють підвищити рівень підготовки та ефективність нормативно-правових актів. Досягнення цієї науки, її прийоми та правила доцільного використання в якості засобу дослідження змісту ЗУ «Про ОРД».

Аналіз публікацій показує наявність значного числа робіт, присвячених різним аспектам оперативно-розшукової діяльності, що знайшло відображення в роботах С.М. Жарова, М.Н. Погорецького, С.І. Захарцева, В.І. Михайлова, Ю.Ф. Кваші, І.А. Климова, В.Н. Омеліна, В.В. Петрова, Г.К. Сінілова та ін. 3 іншого боку, питання юридичної техніки нормативно-правових актів розроблялися в роботах І.Д. Шутака, І.І. Онищука, В.М. Баранова, 
П.М. Робиновича, С.В. Липня, М.Л. Давидової, Т.В. Кашаніної, Г.Т. Чернобель, В.М. Косовича, Ю.О. Тіхомирова та ін. Незважаючи на наявність цих досліджень, розгляд юридичної техніки закону «Про ОРД» не проводився та вимагає свого розроблення.

Метою роботи $\epsilon$ дослідження юридичної техніки ЗУ «Про ОРД» 1992 р.

Виклад матеріалів дослідження необхідно розпочати з того, що питання, пов'язані з оперативно-розшуковою діяльністю, знайшли відображення в нормах Руської Правди, яка регламентувала необхідність «гоніння сліду». У тексті давньої пам'ятки права вказується про таку досудову дію, що має на меті розшук злочинця, згідно з якою на практиці потерпілий разом із родичами чи близькими особами проводив розшук за слідом, а у випадку, коли сліди втрачались біля поселення, потерпілий мав право вимагати від общини або верві відшкодування збитку або видачу злочинця. Якщо верв не могла знайти злочинця, то на неї покладався обов'язок сплатити «дику віру», тобто гроші чи майно, еквівалентне нанесеному збитку. У наступний історичний період в усіх державних утвореннях, які знаходились на території України, проводилися оперативно-розшукові дії у вигляді: спостереження, збору інформації, які здійснювалися оперативними підрозділами. Одночасно із цим почався процес правового регулювання такої діяльності. Наприклад, у дореволюційній Росії діяло «Положення про контррозвідувальні заходи у відділеннях», Настанови з контррозвідки у воєнний час та інші нормативно-правові акти.

Відомий юрист Рудольф фон Ієринг розглядав юридичну техніку як мистецтво застосування права, але в той історичний період розроблення проблематики цієї науки тільки починалося. Ця галузь юриспруденції містить методи, правила, засоби, прийоми створення і систематизації нормативно-правових актів та порядок внесення змін до них.

Поява незалежної України поставила перед суспільством питання правового регламентування оперативно-розшукової діяльності, що знайшло відображення у прийнятті ВР України 18 лютого 1992 р. ЗУ «Про оперативно-розшукову діяльність». Одночасно із цим почались комплексні дослідження у сфері юридичної техніки, яка повинна була забезпечити якісну підготовку нормативно-правових актів та допомогти виявити їхні дефекти з метою вдосконалення змісту та процесу їх підготовки.

Однією з вимог юридичної техніки є мотивація прийняття нормативно-правового акта, тобто має бути правова проблема, розв'язання якої спонукає до прийняття конкретного нормативно-правового акта. Доказом цього положення $\epsilon$ та обставина, що різке зростання злочинності почало спостерігатися в часи створення незалежної України, яка унаслідувала від радянської системи багато невирішених соціальних, економічних та інших проблем.

На думку української дослідниці І.О. Біля, доцільно розділити засоби юридичної техніки на дві групи: а) ті, які регулюють застосування відповідних засобів або прийомів; б) ті, які мають самостійне значення [1, с. 9]. Систематизація цих підходів дозволяє перейти до практичної реалізації юридичної техніки шляхом розгляду низки положень, до числа яких належать такі вимоги: 1) закон має бути соціально значущим; 2) відповідність назви і змісту нормативно-правового акта; 3) консти- туційність законодавчого акта; 4) кількісні показники; 5) системність; 6) забезпечення логіки; 7) мовні правила; 8) формальні вимоги. Виходячи із цього, доцільно детально розглянути зміст кожної вимоги юридичної техніки на прикладі ЗУ «Про ОРД».

І. Соціальна значущість - даний термін означає наявність у законі об'єктивно необхідного для позитивного розвитку комплексу положень та заборон. Виходячи із цього, під час розгляду ЗУ «Про ОРД» необхідно вказати подвійність завдань цього нормативно-правового акта. 3 одного боку, боротьба зі злочинністю вимагає отримання оперативної інформації шляхом здійснення гласних і негласних розшукових дій, які повинні забезпечити якість та законність доказів протиправної діяльності. 3 іншого, у змісті закону необхідно чітко встановити межі таких правовідносин та не допустити порушення конституційних прав і свобод громадян та використання такої інформації в особистих, не визначених законодавством цілях. На думку Г.В. Остафійчука, ця обставина та наявність аспектів, пов'язаних із закритістю інформації, викликають труднощі використання закону «Про ОРД» [2, с. 700]. Так, згідно зі ст. 9 контроль за оперативно-розшуковою діяльністю забезпечується Національною поліцією, Службою безпеки України, Державним бюро розслідування та іншими структурами, яким надано такі повноваження.

II. Відповідність назви і змісту нормативно-правового акта. Назва закону $є$ важливим елементом тексту, має відбивати зміст і предмет. На думку Ж.О. Дзейко, назва закону є орієнтиром для суб' єктів, які здійснюють його застосування, систематизацію, тому, як зазначає вчена, «назва НПА $є$ атрибутом та структурним елементом» [3, с. 38]. Із точки зору юридичної техніки, назва цього закону - «Про ОРД» - $\epsilon$ оптимально стислою, має інформативний характер та розкриває завдання і цілі цього акта. Розгляд співвідношення назви та змісту акта показує відповідність цих категорій, бо цей закон повністю присвячений вирішенню питань, пов'язаних із ОРД. Так, у ст.1 встановлювалося завдання ОРД, ст. 2 присвячена викладенню комплексу заходів, ст. 5 визначає перелік підрозділів, ст. 7 - їхні обов'язки під час проведення оперативно-розшукової діяльності, а у змісті ст. 9 викладено гарантії законності.

III. Конституційність законодавчого акта пов'язана з тим, що закон буде правовим, якщо відповідатиме Конституції, конституційному законодавству, міжнародним правовим договорам, поточним законам, а також прийнятий, опублікований і введений у дію відповідно до встановленої в Конституції процедури. Як наголошує А. О. Селіванов, категорія «конституційність» орієнтує законодавця на вихідну базу правотворчості - первинне конституційне регулювання [4, с. 43].

У радянський період всі заходи, пов'язані з оперативно-розшуковою діяльністю, мали гриф секретності i не були доступні для ознайомлення громадян, що обмежувало їх конституційні права. У незалежній Україні діє Конституція 1996 року, згідно зі ст. 9 якої кожна людина має право на свободу особистості та недоторканність. В інших положеннях основного закону вказується про тайну переписки, недоторканність житла, сімейного життя. Одночасно із цим ст. 64 вказує, що конституційні права і свободи людини, громадянина не можуть бути обмежені, крім випадків, передбачених Конституцією України. Із цієї точки зору необхідно вка- 
Кількісні показники Закону України «Про ОРД» 1992 р.

Таблиця 1

\begin{tabular}{|c|l|c|c|}
\hline № & \multicolumn{1}{|c|}{ Стаття } & 3 3н. & $\%$ \\
\hline 1 & Завдання оперативно-розшукової діяльності & 516 & 1,09 \\
\hline 2 & Поняття оперативно-розшукової діяльності & 226 & 0,48 \\
\hline 3 & Правова основа оперативно-розшукової діяльності & 893 & 1,88 \\
\hline 4 & Принципи оперативно-розшукової діяльності & 206 & 0,43 \\
\hline 5 & Підрозділи, які здійснюють оперативно-розшукову діяльність & 3538 & 7,47 \\
\hline 51 & Міжнародне співробітництво у сфері оперативно-розшукової діяльності & 631 & 1,33 \\
\hline 6 & Підстави для проведення оперативно-розшукової діяльності & 2900 & 6,12 \\
\hline 7 & Обов’язки підрозділів, які здійснюють оперативно-розшукову діяльність & 4074 & 8,60 \\
\hline 8 & Права підрозділів, які здійснюють оперативно-розшукову діяльність & 8648 & 18,25 \\
\hline 9 & Гарантії законності під час здійснення оперативно-розшукової діяльності & 10041 & 21,19 \\
\hline 91 & Строки ведення оперативно-розшукових справ & 6307 & 13,31 \\
\hline 92 & Закриття оперативно-розшукових справ & 2066 & 4,36 \\
\hline 10 & Використання матеріалів оперативно-розшукової діяльності & 1203 & 2,54 \\
\hline 11 & Сприяння здійсненню оперативно-розшукової діяльності & 1224 & 2,58 \\
\hline 12 & Соціальний і правовий захист працівників оперативних підрозділів & 1224 & 2,58 \\
\hline 13 & $\begin{array}{l}\text { Соціальний і правовий захист особи, яка залучається до виконання завдань оперативно- } \\
\text { розшукової діяльності }\end{array}$ & 698 & 1,46 \\
\hline 14 & Нагляд за додержанням законів під час проведення оперативно-розшукової діяльності & 2999 & 6,33 \\
\hline & Загальна кількість знаків & 47394 & 100 \\
\hline
\end{tabular}

зати, що специфіка оперативно-розшукових дій передбачає у випадках протидії злочинам обмеження деяких конституційних прав і свобод. Закон «Про ОРД» містить положення, які дозволяють використовувати систему стримання та взаємопротиваг. Так, ст. 7 дозволяє підрозділам, що здійснюють оперативно-розшукову діяльність, вживати необхідні заходи щодо попередження злочинів, до числа яких входять: збір інформації, контроль за пересуванням, прослуховування, негласне обстеження житла, огляд та виїмка кореспонденції та ін. На противагу цьому ст. 9 надає право громадянам України та іншим особам одержувати від органів, що проводять оперативно-розшукову діяльність, письмові пояснення із приводу обмеження їхніх прав і свобод та оскаржувати такі дії. На додаток цього закон забороняє оприлюднення або надання зібраної в результаті оперативно-розшукових дій інформації.

IV. Кількісні показники нормативно-правових актів дають уявлення про цифрові характеристики, розподіл матеріалу всередині документу та можливість виділити напрямки правотворчості, яким приділено найбільшу увагу. Для таких розрахунків було використано методику, запропоновану О.Л. Копиленко та Б.В. Кіндюком, яка включала в себе встановлення кількості знаків, що входять до кожної зі статей акта, з подальшим їх перерахунком в \% від загальної кількості знаків [5, с. 6]. Так, згідно з отриманими результатами найбільше їх значення припадає на ст. 9, в якій міститься 10041 зн., чи 21,2\% від загального числа (табл. 1). На другому місті - ст. 8 - число знаків складає 8648, чи 18,3\%, на третьому - ст. $9^{1}$ - 6307 зн., чи 13,3\% Ці дані свідчать, що найбільшу увагу законодавці приділили гарантіям

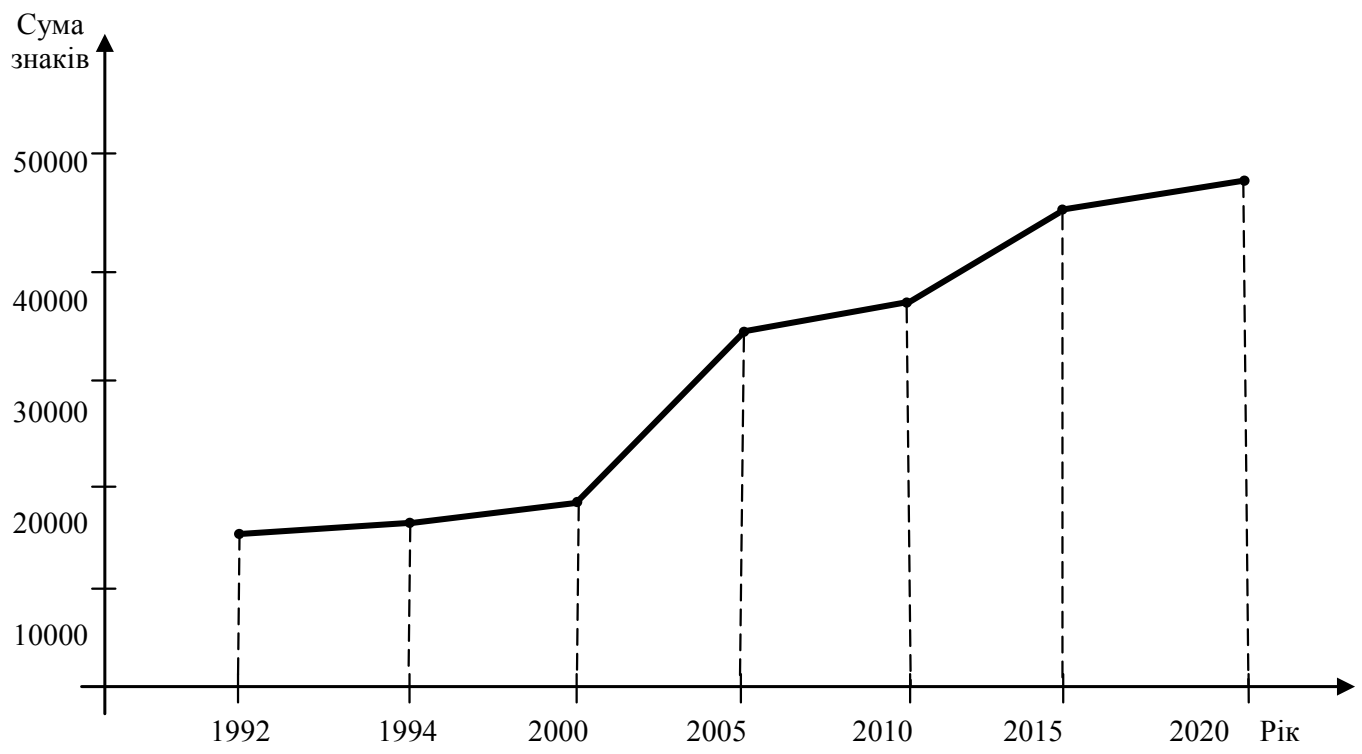

Рис. 1. Динаміка кількості знаків у різних редакціях ЗУ «Про ОРД» 
законності під час здійснення оперативно-розшукової діяльності. Достатньо дивно розглядати факт того, що найменша увага, тобто найменша кількість знаків - 206, чи $0,4 \%$ - приходить на принципи оперативно-розшукової діяльності (табл. 1).

За допомогою кількісних показників можна дослідити динаміку інтенсивності правотворчості за допомогою даних стосовно загального числа знаків у законі. Так, на момент прийняття закону «Про ОРД» документ складався з 15691 зн., за станом 1994 р. цей показник дорівнює 16170 зн., у 2000 р. - 18544 зн., 2005 р. - 34109 зн., 2010 р. - 37745 зн., 2015 р. - 46487 зн. і у 2020 р. 47394 зн. (рис. 1).

Розглядаючи графік, який показано на рис. 1, можемо отримати уявлення про поступове збільшення сум знаків, тобто в цілому за період з 1992 р. по 2020 р. обсяг актового матеріалу став більшим у три рази. Такі результати показують процес поступового ускладнення правовідносин та збільшення кола питань, які входили до процесу правового регулювання оперативно-розшукової діяльності.

V. Системність становить собою закономірну властивість права, на основі якої впорядковуються наявні в нормативно-правових актах приписи. За допомогою цієї категорії всі елементи права пов'язані між собою ієрархічно, генетично та функціонально. Як зазначає Л.І. Заморська, лише системно впорядковане право здатне ефективно виконувати завдання з регулювання суспільних відносин та досягти цілей, які постають перед юридичною наукою [6, с. 32]. Така властивість простежується на прикладі ст. 7, в якій iï частини утворюють впорядковану цілісну єдність, що будується на змістовних підставах. Так, органи, що здійснюють оперативно-розшукову діяльність, зобов'язуються вживати необхідні заходи щодо попередження, виявлення злочинів, виконувати письмові доручення слідчого, вказівки прокурора, суду, запити правоохоронних органів інших держав, інформувати державні органи, здійснювати взаємодію між собою та іншими правоохоронним органами, забезпечувати безпеку працівників суду і правоохоронних органів. Ці зобов'язання утворюють структурну систему, яка відповідає вимогам стійкості та відносної самостійності. Доказом відповідності ст. 7 даній закономірності $\epsilon$ та обставина, що внесення в неї доповнень у 2000, 2001, 2003, 2012, 2015, 2016 роках не змінило iї структурного упорядкування.

VI. Забезпечення логіки пов'язано з тією обставиною, що нормативно-правовий акт містить у собі модель того процесу, який покликаний регулювати правовідносини та логіку поведінки його учасників. Від рівня логіки нормативного-правового акта залежить і рівень регулювання моделі поведінки. Логіка Закону «Про ОРД» пов'язана з необхідністю протидії злочинності шляхом проведення оперативно-розшукової діяльності, яка являє систему гласних і негласних пошукових дій розвідувальних та контррозвідувальних заходів. На зміст цієї вимоги впливають, як вказує В.О. Білецький, такі характеристики ОРД, як швидкість реагування, конфіденційність, залучення широкого кола інформації та проведення комплексу необхідних заходів [7, с. 143]. Логіка Закону «Про ОРД» включає можливість, того, що гласні заходи можуть мати нег- ласну мету, наприклад, за наявності заяви про злочин оперативні працівники можуть отримувати потрібну інформацію без згоди заявника. Дію юридичної логіки, яка включає в себе вимогу раціональності, можна дослідити на прикладі ст. 10, яка регламентує використання матеріалів ОРД. Закон передбачає можливість отримання за їх допомогою фактичних даних, які будуть доказами у кримінальному провадженні, приводами та підставами для початку досудового розслідування, попередження, виявлення, розслідування злочинів та ін. Такий виклад матеріалу у ст. 10 забезпечує ефективність юридичної конструкції цієї статті та дає гарантії їі виконання на практиці.

VII. Мовні правила пов'язані з тим, що мова являє собою основний засіб передачі будь-якої інформації та $\epsilon$ зовнішньою формою будь-якого змісту. Мова права має певні особливості, до яких належать: офіційність, ясність, точність, однозначність, повнота змісту, нормативність та стабільність, а також забезпечення відсутності двозначності у трактуванні правових норм. Мовні питання у змісті Закону «Про ОРД» досліджували П.П. Підюков, І.В. Сервецький, які вказували на зв'язок термінології та наукового стилю даної категорії [8, с. 431]. Виходячи із цього підходу, можна вказати, що акт відрізняється якістю мови, використанням чітких формулювань та понять, зрозумілих для користувачів акта. Недоліком документу $є$ відсутність статті, в який викладені основні терміни закону, що значно ускладнює практичне використання закону.

XIII. Формальні вимоги закону «Про ОРД» забезпечуються виконанням положень щодо порядку прийняття акта, у змісті міститься номер, дата прийняття, підпис Президента України, який затвердив даний документ, а також посилання стосовно його оприлюднення у Відомостях Верховної Ради України.

За результатами проведеного дослідження можна зробити такі висновки:

1. Зміст закону відповідає вимозі соціальної значущості, яка полягає у протидії злочинності; назва документу відповідає змісту акта, а розподілення статей забезпечує вимогу логіки вкладення матеріалу.

2. Показано, що за допомогою кількісних показників автори документу найбільшу увагу приділяли гарантіям законності під час проведення ОРД, а також очевидним $\epsilon$ факт поступового збільшення обсягу текстового матеріалу, який у період з 1992 р. по 2020 р. збільшився майже у 3 рази.

3. Недоліком законодавчого акта $€$ необхідність більш чіткого викладення та збільшення обсягу матеріалу, присвяченого забезпеченню конституційних прав і свобод людей та громадян.

\section{Література}

1. Биля І.О. Теоретичні основи використання нормотворчої техніки : дис. ... канд. юрид. наук. Харків, 2004. 201 c.

2. Остафійчук Г. В. Співвідношення ОРД та кримінального процесу на досудових стадіях. Форум права. 2010. № 4. С. 700-704.

3. Дзейко Ж.О. Техніко-юридичні правила конструювання назви закону. Проблеми законодавчого регулювання порядку розробки та прийняття нормативно-правових актів: матеріали III Міжнар. наук.-практ. конф. / за заг. ред. І.Д. Шутака (м. Київ, 2-3 листоп. 2017 р.). Харків : Право, 2017. С. 37-40. 


\section{Актуальні проблеми історико-правової та міжнародно-правової науки}

4. Селиванов А.А., Стрижак А.А. Вопросы теории конституционного правосудия в Украине: актуальные вопросы современного развития конституционного правосудия. Киев : Логос, 2010. 272 с.

5. Копиленко О.Л., Кіндюк Б.В. Теоретичні засади використання кількісних показників у дослідженнях пам'яток права. Юридична Україна. 2016. № 7-8. С. 4-12.

6. Заморська Л.І. Системність та нормативність у праві: діалектика взаємодіі. Порівняльно-аналітичне право. 2013. № 2. С. 31-33.

7. Білецький В.О. Законопроектна увага до оперативно-розшукової діяльності з боку Верховної Ради України
VIII скликання. Вісник Національної академії Державної прикордонної служби України. 2018. № 4. С. 141-144.

8. Підюков П.П., Сервецький І.В., Юрченко О.М. Оперативно-розшукова діяльність як форма застосування оперативно-розшукового права: правова природа і сутність поняття. Науковий вісник Львівського державного університету внутрішніх справ. 2010. № 1. С. 428-436.

Аброськін В. В., кандидат юридичних наук, генерал поліції II рангу, ректор Одеського державного університету внутрішніх справ 